\title{
Protasis and Apophansis in Aristotle's Logic
}

\section{Aristoteles Mantı̆gnda Protasis ve Apophansis}

\author{
MURAT KELIKLİ
}

Bartın University

Received: 02.12.2018 | Accepted: 28.12.2018

\begin{abstract}
This essay examines how Aristotle creates propositions. It evaluates his use of quality and quantity in his theory of syllogism. In De Interpretatione, Aristotle used the term, 'apophansis', but he preferred 'protasis' in Analytica Priora. While Aristotle classified these as affirmative and negative due to their qualities, he embraced a different point of view about classifications based on quantity. Differences in apophansis are evaluated on the basis of their singular and universal structures, and their predications are also taken into consideration. As he studied protasis, however, he re-arranged the classifications of apophansis and re-shaped them according to their predicative properties. The structural difference between De Interpretatione and Analytica Priora are revealed through a careful examination of Aristotle's use of these two concepts.
\end{abstract}

Keywords: Proposition, protasis, apophansis, singular, universal, Aristotelian logic. 


\section{Introduction}

In his famous book, Łukasiewicz asked "why singular terms were omitted by Aristotle" (Łukasiewicz I957: I.3). Similarly, we can ask, "why were indefinite terms omitted by Aristotle?" Łukasiewicz asks this question of Analytica Priora, but he disregarded Aristotle's investigation of them in De Interpretatione, which should also be given attention. This essay intends to show the differences in the way that Aristotle examined

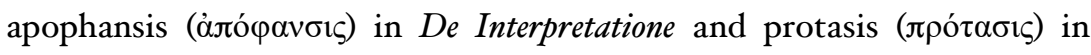
Analytica Priora. He did not omit singular and indefinite terms and instead showed how to construct syllogisms by use of these apophansis

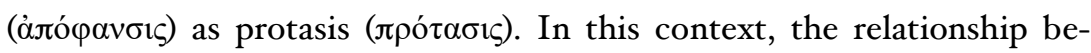
tween apophansis and protasis will be explored, including why Aristotle used different terms and classifications in each of these works.

In De Interpretatione, Aristotle examined apophansis (ảंó $\varphi \alpha v \sigma \iota)$, and in Analytica Priora, he instead spoke of protasis ( $\pi \rho$ ó $\tau \alpha \sigma \iota)$ ). Both how these terms should be translated and how the relationship or correlation between them should be understood are important issues. Which terms correspond to proposed notions such as proposition, statement, assertion, premise, etc. is not clear from a straightforward reading of Aristotle's syllogistic theory. Often, different but related notions of assertion have been translated with the same terms. How these terms are translated to English is important at a conceptual rather than only linguistic level. Aristotle supplied a definition of logos (I prefer, 'logos' for ' $\lambda$ ó $\gamma \circ \varsigma^{\prime}$ ):

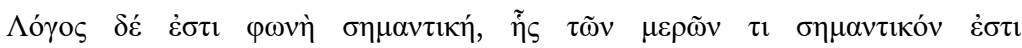

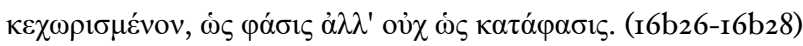

$\Lambda$ ó ${ }^{\circ} \varsigma$ is a significant spoken sound (gestures) some part of which is significant in separation - as an expression, not as an affirmation. ${ }^{\text {. }}$

Aristotle further defines logos:

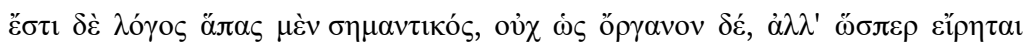

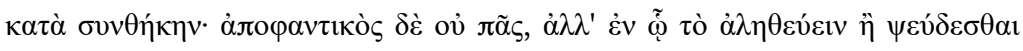

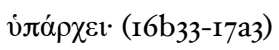

\footnotetext{
I Translation: Ackrill, 20I4. For the sake of notional clarity, however, all references to the Ancient Greek texts are instead from Minio-Paluello, L., Oxford Classical Texts, I949 \& Ross, W. D. and Minio-Paluello, L., Oxford Classical Texts, 1964
} 
Every [logos] is significant (not as a tool but, as we said, by convention), but [not all of them] is a apophantikos, but only those in which there is truth or falsity. ${ }^{2}$

From this statement, it is clear that some logos are not affirmations or negations. But some clearly are:

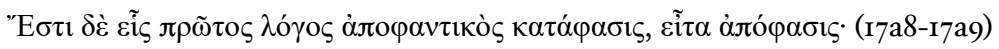

The first single [proposition-being logos] is the affirmation, next is the negation. ${ }^{3}$

In paragraph I6b26, truth and falsity exist as some characters of logos; accordingly, these are noted as affirmation and negation in paragraph I7ar. Thus, 'proposition-being logos', which is an affirmation or negation, also has a truth-value. Therefore, this Aristotelian understanding of proposition, by virtue of its having a truth-value, can be understood with the contemporary term 'proposition'. One kind of logos is the proposition. And Aristotle classifies propositions as ' $\dot{\alpha} \pi \lambda \cos ^{\circ}$ (simple):

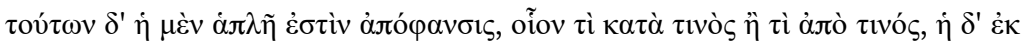

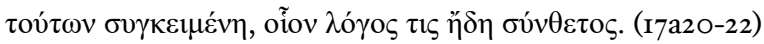

Some of these propositions are simple, e.g. something to something or something of something; the others are compounded of them, e.g. a kind of composite logos. ${ }^{4}$

Additionally, Aristotle gives the definition of ' $\dot{\alpha} \pi \lambda \tilde{\eta} \dot{\alpha} \pi$ ó $\varphi \alpha v \sigma \iota \varsigma^{\prime}$ as;

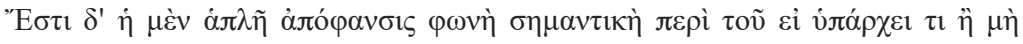

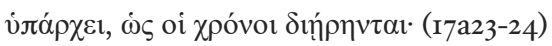

The simple proposition is a significant spoken sound (gestures) about whether something does or does not [belong to], [according to] the divisions of time. ${ }^{5}$

This is because a proposition is simple ( $\dot{\alpha} \pi \lambda \cos )$, asserting only one truth-value (2ObIO-I2). Every 'simple proposition' is either true or false. But as every 'non-simple proposition' makes more than one affirmation or negation. Hence, it has more than one truth-value.

\footnotetext{
2 Translation is modified from Ackrill, 2014.

3 Translation is modified from Ackrill, 2014.

4 Translation is my own.

5 Translation is modified from Ackrill, 2014.
} 
Consider another of Aristotle's definitions, this one of protasis

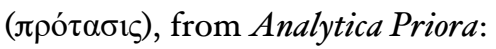

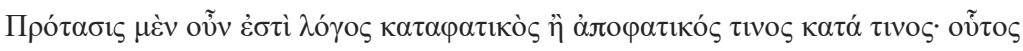

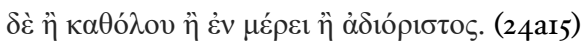

Прó $\alpha \sigma \iota \varsigma$, then, is a logos affirming or [negating] something [to] something; and this is either universal or particular or indefinite. ${ }^{6}$

According to this definition, protasis ( $\pi \rho$ ó $\alpha \alpha \sigma \iota)$ corresponds to 'proposition', but in order not to confuse matters, it would be helpful to use a new term: it can be equivalent to 'premise', but there are some challenges with this new term. Crivelli and Charles remark that

He [Aristotle] applies ' $\pi \rho{ } \tau \alpha \sigma \iota \varsigma$ ' to the conclusion of a syllogism. Thus,

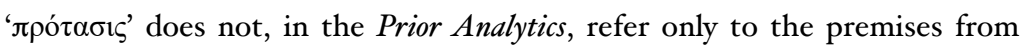
which the conclusion is derived. It follows that ' $\pi \rho{ }^{\prime} \tau \alpha \sigma \iota \varsigma^{\prime}$, as used in the Prior Analytics, is not coextensive, nor equivalent in sense, with 'premise'. (Crivelli \& Charles 20II: I98)

I agree with this concern, but if protasis ( $\pi \rho$ ó $\tau \alpha \sigma 1 \varsigma)$ continues to be translated as 'proposition', then there is no way to show that it does not have many truth-values. This distinction is important, because Aristotle says that protasis ( $\pi \rho \tau^{\tau} \alpha \sigma 1 \varsigma$ ) is a different concept than that of the proposition. As follows, protasis ( $\left.\pi \rho{ }^{\tau} \tau \alpha \sigma \iota\right)$ defined in this way requires emphasizing the simple ( $\dot{\alpha} \pi \lambda \operatorname{ó} \varsigma)$ character of assertion:

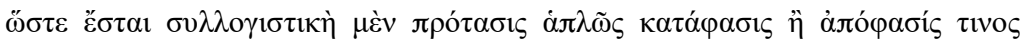

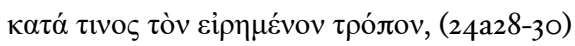

Therefore, a deductive $\pi \rho o ́ \tau \alpha \sigma ı \varsigma$ will be an simple affirmation or [negation] of something [to] something in the way we have described. ${ }^{7}$

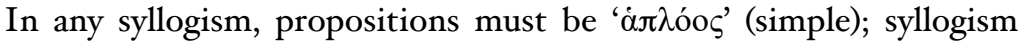
can only be made up of them (34b7-I8). In this case, we can say that, protasis $(\pi \rho{ } \tau \alpha \sigma 1 \varsigma)$ is equivalent to simple propositions. The protasis ( $\pi \rho \sigma^{\tau} \alpha \sigma 1 \varsigma$ ) concept and study in Analytica Priora are different than Aristotle's understanding of propositions in De Interpretatione. As such, it is clear that protasis ( $\left.\pi \rho \cos _{\alpha \sigma \iota)}\right)$ is true or false, and as such, it must be un-

6 Translation is modified from Jenkinson, 2014.

7 Translation is modified from Jenkinson, 20I4. 
derstood as a different concept than the proposition. ${ }^{8}$ So protasis

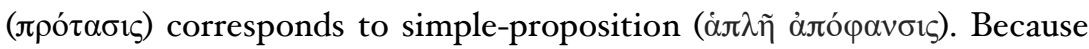
of these differences, Aristotle needed to develop a new term. In my opinion, there has not yet been a sufficient translation of protasis ( $\pi \rho$ ó $\tau \alpha \sigma \iota)$, so it must be rendered as 'Protasis'.'

\section{The Proposition in the Work of Aristotle}

The first division of propositions in Aristotle is that between the af-

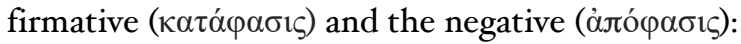

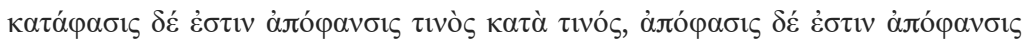

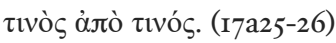

An affirmation is a [proposition] affirming something [to] something, a negation is a proposition [negating] something [from] something. ${ }^{\circ}$

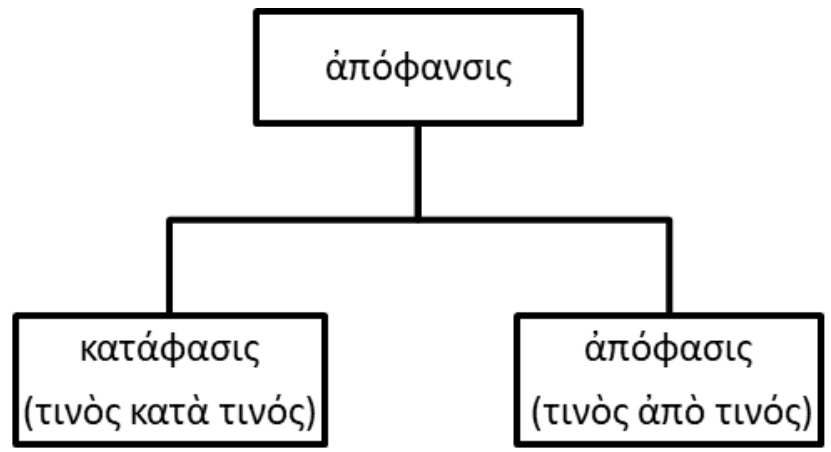

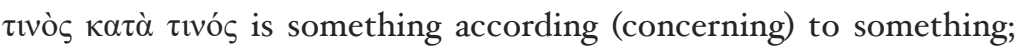

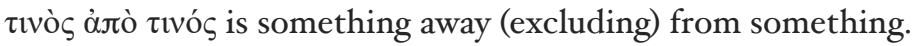

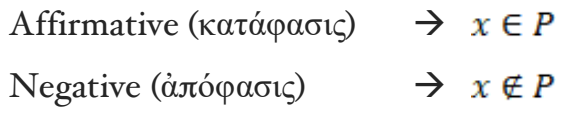

If predication occurs only to one something, then the proposition is singular; if something is instead predicated to more than one element by whole or part, it is universal. That is, for singular propositions, predication contains only one element; for a universal proposition, predication contains more than one.

8 Structural differences between the two types of propositions in the two texts will be examined in the next section.

9 Corcoran and Boger have similar embarrassment to translate protasis. They discussed this point in a different concept (Corcoran and Boger, 2OII: I5I-2).

Io Translation is modified from Ackrill, 2014 . 


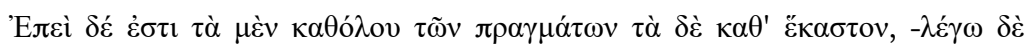

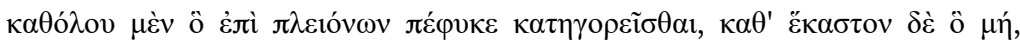
(I7a38-40)

Now of actual things some are universal, others [singular] - I call universal that which is by its nature predicated of [more] of thing, and [singular] that which is not. ${ }^{\text {II }}$

Based on Aristotle's definition, further specification of the types of propositions may be made: there are those in which predication applies

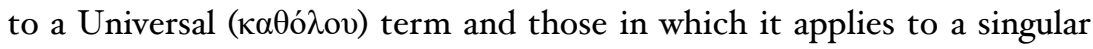

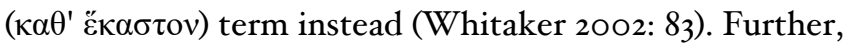

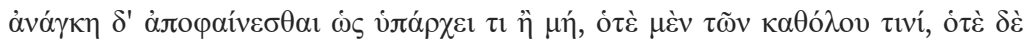
$\tau \tilde{\omega} \nu \kappa \alpha \theta^{\prime} \varepsilon \tilde{\kappa} \alpha \sigma \tau \mathrm{ov} .(\mathrm{I} 7 \mathrm{bI}-3)$

It is necessary to propositions that belong to or doe not, some of them as universal, some of them as singular. ${ }^{\mathrm{I2}}$

It is clear that in this distributed understanding, there is no a third option. For instance, 'human' and 'Kallias' will be universal or singular terms according to how they are predicated. Due to predication, 'human' will be a plural; 'human' is universal term. This sort of predication can be either of all elements belongings to 'human' or only to one of them. The important point is that there is a larger group that could predicated of. A man whose name is 'Kallias' is only one, though, so predication occurs by way of one; as such,'Kallias' is a singular term.

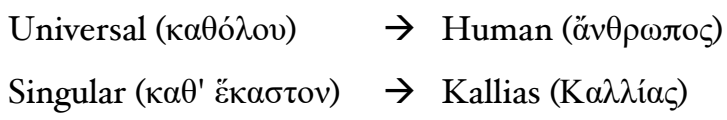

Aristotle has given examples here that show how general use of a name may vary depending on the use. For instance, we may take 'Kallias' not as an singular but instead as all of the people named 'Kallias'. In this case, it will be understood as a universal term. If this is so, then predication can occur related to either all of the singulars belonging to the group or instead only to one of the 'Kallias'. Determining whether a term is singular or universal requires examining how it is being used. This same theme can be seen in an example that Aristotle gives for induction,

\footnotetext{
II Translation is modified from Ackrill, 2014.

${ }^{12}$ Translation is my own.
} 
in which he indicates that a universal category consists of the combination of many singulars.

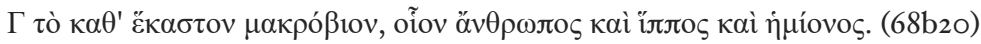

$\Gamma$ for the long-lived singulars such as man and horse and mule. ${ }^{13}$

In this case, 'long-lived' is applied to an singular 'human' and 'horse' and 'mule'. So here, 'human' is singular term. In this case, the intent is not 'a human' in general, but rather a singular person. Although the term 'human' adopts a universal structure, in the context of singular humans and their long or short lives, as in the above use of 'human', this is clearly a case of the term being used to refer to a singular. By Aristotle's theory of induction, however, each of these singulars combines to create a universal made up of singulars. This understanding helps to make sense of passages such as this one:

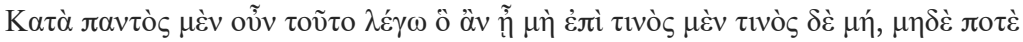

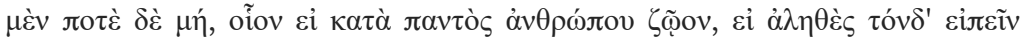

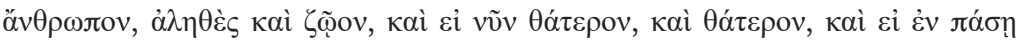

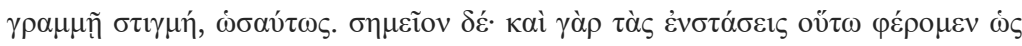

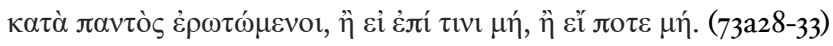

Now I say that something holds of every case if it does not hold in some cases and not others, nor at some times and not at others; e.g. if animal holds of every man, then if it is true to call this a man, it is true to call him an animal too; and if he is now the one, he is the other too; and the same goes if there is a point in every line. Evidence: when asked if something holds of every case, we bring our objections in this way-either if in some cases it does not hold or if at some time it does not. ${ }^{\mathrm{I}}$

Universal predication occurs over singular terms; this is a process whereby a predicate applies one by one to all singular members of a sub-

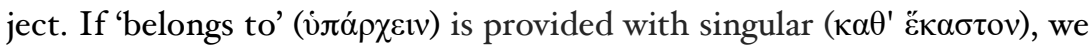
look only at this as a category. If 'belongs to' (نં $\dot{\alpha} \rho \chi \varepsilon \imath v)$ is provided with

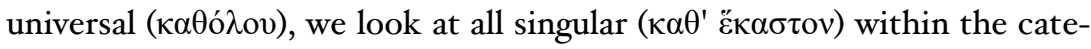
gory.

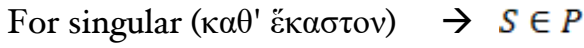

${ }^{13}$ Translation: Tredennick, 1938 .

${ }^{14}$ Translation: Barnes, 2014. 


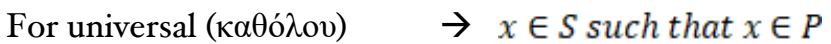

Stated simply, predication is not directly from or to the universal; rather, it is from all of those singulars within a universal category.

The quantity of a propositions is determined according to its subject, i.e. if the subject term is singular, then proposition is also singular; likewise, if the subject term is universal, then the proposition will be as well. Aristotle distinguished two parts in universal propositions that establish whether predication occurs universally or not universally:

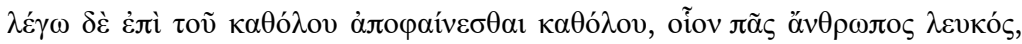

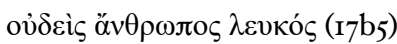

I mean by 'stating universally of a universal' are: every man is white - no man is white. ${ }^{15}$

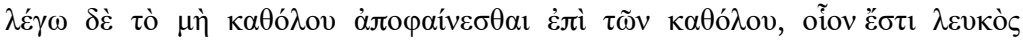

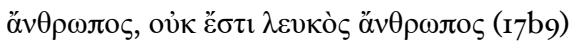

I mean by 'stating of a universal not universally' are: man is white - man is not white. ${ }^{16}$

Aristotle categorized propositions as follows: According to Aristotle, the terms predicate each one to another. So a universal can predicate to a universal, singular to universal. But it cannot predicate universal to singular (ı7a38-bı6). This is also mentioned in the Analytica Priora:

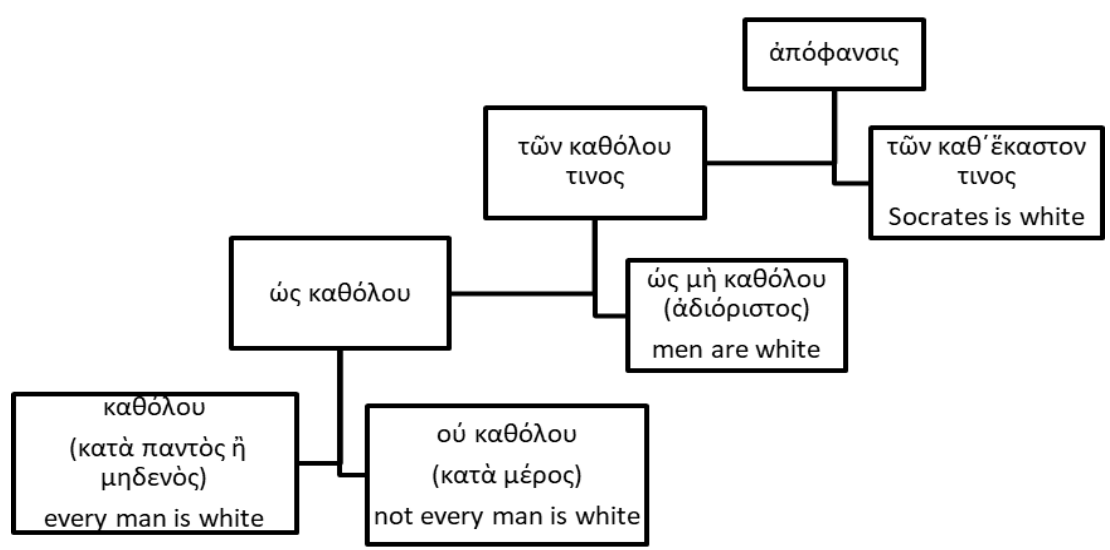

${ }_{15}$ Translation: Ackrill, 2014.

${ }^{16}$ Translation is modified from Ackrill, 2014. 


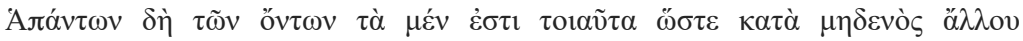

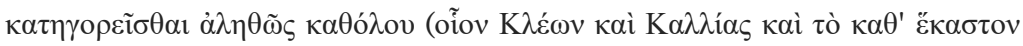

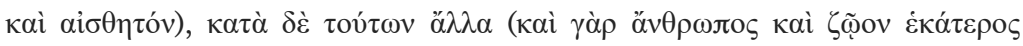

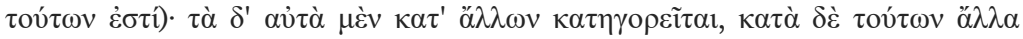

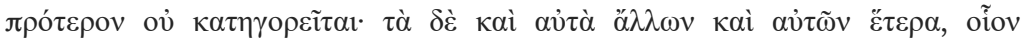

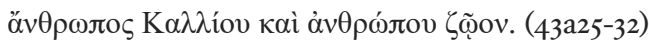

Of all the things which exist some are such that they cannot be predicated of anything else truly and universally, e.g. Cleon and Callias, i.e. the singular and sensible, but other things may be predicated of them (for each of these is both man and animal); and some things are themselves predicated of others, but nothing prior is predicated of them; and some are predicated of others, and yet others of them, e.g. man of Callias and animal of man. ${ }^{17}$

In some situations, singular terms can be found in predication. But this predication appears only incidentally.

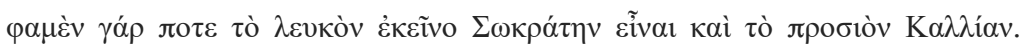
(43a35)

for we sometimes say that that white object is Socrates, or that that which approaches is Callias. ${ }^{\mathrm{I} 8}$

But these cannot use for deduction:

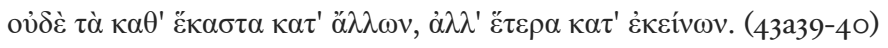

Neither can singulars be predicated of other things, though other things can be predicated of them. ${ }^{19}$

For a proposition such as, "every one of these organs are Socrates", 'Socrates' is predicated to 'organs' as accidental. All of these organs in total are Socrates, but one by one, treated as singulars, they are not Socrates. This is not compatible with the earlier definition of 'belongs to' (ijá $\rho \chi \varepsilon i v)$. See, for instance, what occurs where there is an attempted combination of "all of these organs is Socrates", and "one by one these organs are not Socrates". This does not check out with 'belongs to' (iภá $\rho \chi \varepsilon v$ ). An absurd syllogism like this would then be warranted:

\footnotetext{
${ }^{17}$ Translation: Jenkinson, 2014.

${ }^{18}$ Translation: Jenkinson, 2014.

${ }^{19}$ Translation: Jenkinson, 2014.
} 
Socrates is a philosopher

Every one of these organs is Socrates

Hence, every one of these organs is philosopher

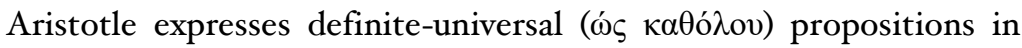
De Interpretatione as follows:

Every man is white

Not every man is white

Some men are white

No man is white

Here the terms "Every, Some ..." signify definite-universal statements; i.e. it shows the proposition's quantity;

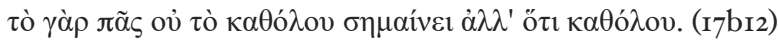

For 'every' does not signify the universal but that it is taken universally. ${ }^{20}$

Hamilton indicates (I860: 277) that if we take quantity of not only subjects but also predications, we have eight possible types of propositions:

All $\mathrm{A}$ is all $\mathrm{B}$

Any $\mathrm{A}$ is not any $\mathrm{B}$

All $\mathrm{A}$ is some $\mathrm{B}$

Any $\mathrm{A}$ is not some $\mathrm{B}$

Some A is all B

Some A is not any B

Some A is some B

Some A is not some B

There is no question of quantity of predication in Aristotle. He explains that predication is universal but cannot take universally of universal;

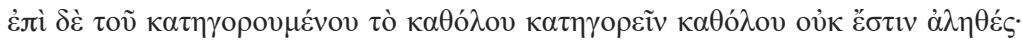

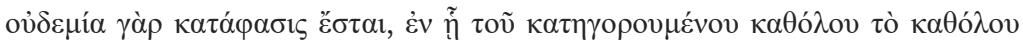

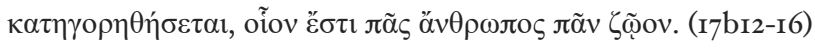

It is not true to predicate a universal universally of a subject, for there cannot be an affirmation in which a universal is predicated universally of a subject, for instance: every man is every animal. ${ }^{2 \mathrm{I}}$

So we have these propositions;

\footnotetext{
${ }^{20}$ Translation: Ackrill, 2014.

${ }^{21}$ Translation: Ackrill, 2014.
} 
Socrates is white

Socrates is not white

Men are white

Men are not white

Every man is white

Not every man is white

Some man is white

Any man is not white $s \in W$

$s \notin W$

$x \in M$ such that $x \in W$

$x \in M$ such that $x \notin W$

$\forall x \in M$ such that $x \in W$

$\exists x \in M$ such that $x \notin W$

$\exists x \in M$ such that $x \in W$

$\forall x \in M$ such that $x \notin W$

\section{Protasis in the Work of Aristotle}

There is no kind of protasis as singular evaluated in the Analytica Priora; from this assessment, one might think that Aristotle passes over the singular protasis altogether. In this context, we see for the first time par-

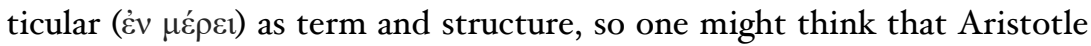
also passes over particular propositions in De Interpretatione. Both of these assessments are unwarranted. We see the particular proposition is included in a discussion of the universal in De Interpretatione. Aristotle evaluated particular protasis separately in Analytica Priora. Because particular propositions make use of universal propositions to take part of the universal, they are used like universal (23ar7). We see Aristotle's consideration in Analytica Priora about indefinite protasis as follows:

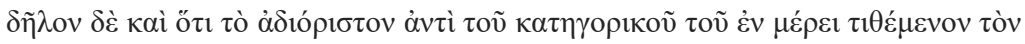

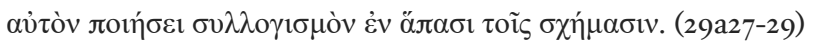

It is evident also that the substitution of an indefinite for a particular affirmative will effect the same deduction in all the figures. ${ }^{22}$

Especially, we see some discussion of this in chapter four. He says, in the first figure, indefinite protasis must occur as particular;

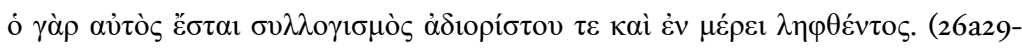
30)

for we shall have the same deduction whether it is indefinite or particular. ${ }^{23}$

\footnotetext{
${ }^{22}$ Translation: Jenkinson, 20I4.
}

23 Translation: Jenkinson, 20I4. 
Avicenna describes the situation as follows;

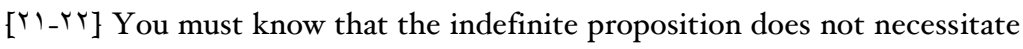
generalization. This is because in it there is mention of a nature which can be either properly taken universally or properly taken particularly. Taking it purely [i.e., by itself], without linkage [to a quantity indicator] does not necessarily make it universal. If that were necessarily to impose universality and generality on it, then the nature of "human being" would have necessarily been general - and thus an singular would not be a human being. But since it can be properly taken universally, and there, it can also be applicable particularly; for that which is predicated of all is predicated of some - the same being true of [that which is predicated] negatively - and [since] it can be properly taken particularly, then in the two cases its judgment is applicable particularly. Thus the indefinite proposition is of the same force as that of the particular one.

But the fact that a proposition is explicitly applicable particularly does not prevent it from being at the same time applicable universally. / For if a judgment is made about some, it does not follow from this that the rest is the opposite. Thus even though the indefinite proposition is explicit of the same force as a particular one, there is nothing to prevent it from being applicable universally. (Ibn-Sīnā I984: 8I-82). ${ }^{24}$

This professes agreement with a definition of Aristotle's indefinite protasis, and as Aristotle claimed:

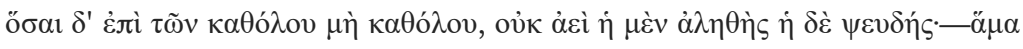

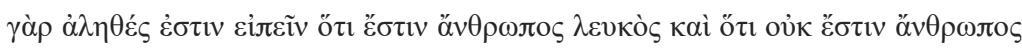

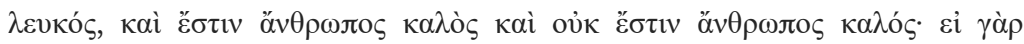

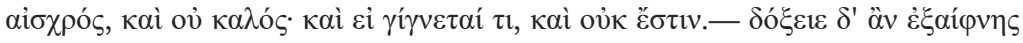

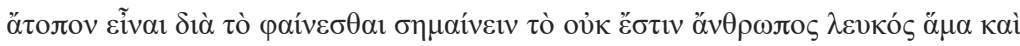

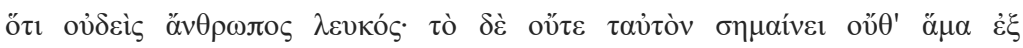

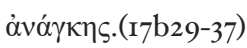

But if they are about a universal not taken universally it is not always the case that one is true and the other false. For it is true to say at the same time that man is white and that man is not white, or that man is noble and man is not noble (for if base, then not noble; and if something is becoming some-

${ }^{24}$ Translation: Inati, 1984 
thing, then it is not that thing). This might seem absurd at first sight, because 'man is not white' looks as it if signifies also at the same time that no man is white; this, however, does not signify the same, nor does it necessary at the same time. ${ }^{25}$

Indefinite protasis cannot make universal claims. As such, indefinite protasis will set out like particular protasis, i.e. Aristotle understands indefinite protasis as particular protasis.

In Aristotle's logic, it is obvious that singular propositions are a protasis. So, Aristotle explains for singular problems as follows;

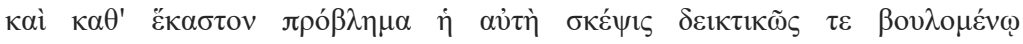

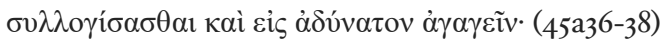

[and singular problem], the same inquiry is necessary whether one wishes to use a probative deduction or a reduction to impossibility. ${ }^{26}$

also he explains how to take this kind of problem in a previous chapter;

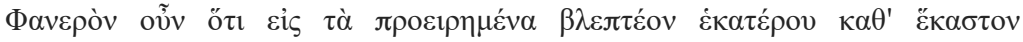

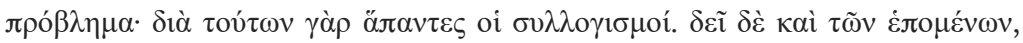

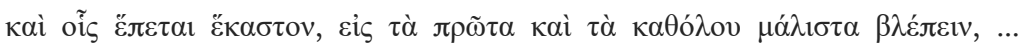
(44а36-39)

It is clear then that in [singular] problem we must look to the aforesaid relations of the subject and predicate; for all deductions proceed through these. But if we are seeking consequents and antecedents we must look especially for those which are primary and universal... ${ }^{27}$

Then, we come to see that singular affirmative or negative protasis implement as universal affirmative or negative protasis. In this case, protasis varieties can be created according to Aristotle:

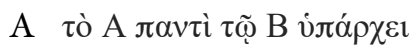
$\mathrm{BaA}$

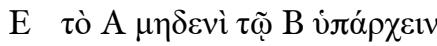
$\mathrm{BeA}$

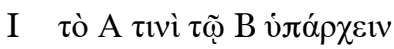
$\mathrm{BiA}$

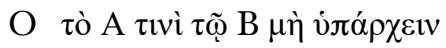
BoA

With this in mind, it is important to see that there is a structural dif-

\footnotetext{
25 Translation: Ackrill, 2014.

${ }^{26}$ Translation is modified from Jenkinson, 20I4.

${ }^{27}$ Translation is modified from Jenkinson, 20I4.
} 
ference between propositions and protasis. Simple propositions and prot-

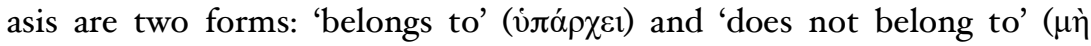

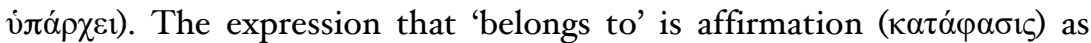

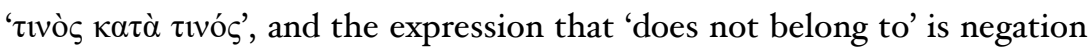

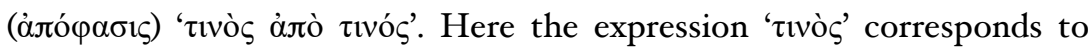

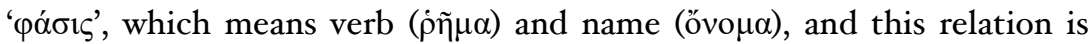
made by the act itself being the verb or by being connected with 'to be' (cini). However, since a grammatical approach is not suitable for formal

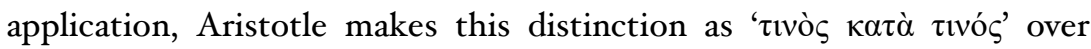

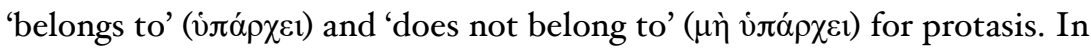

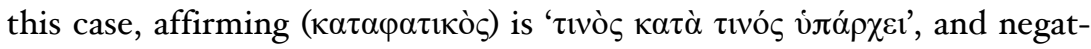

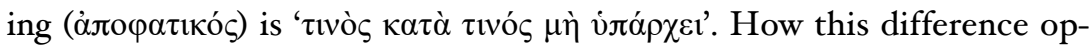
erates is clear in the following expression:

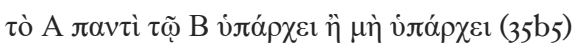

Aristotle shows, in this notation, examples of both universal affirmative and universal negative protasis. So we understand this is a negative predication of the verb. Aristotle has examined this equivalence in $D e$ Interpretaione $\mathrm{X}$ :

Every man is non-white $\equiv$ No man is white

$B a \bar{A} \equiv B e A$

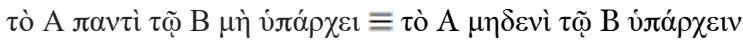

Thus, Aristotle regulated protasis in this manner:

BaA $\forall x \in B$ such that $x \in A$

BeA $\forall x \in B$ such that $x \in \bar{A}$

BiA $\exists x \in B$ such that $x \in A$

BoA $\exists x \in B$ such that $x \in \bar{A}$

Aristotle builds his theory on these four protases. All other propositions are constructed on these four protases. Since other types of proposition ensure compliance with the form established by these propositional varieties, there is no need to treat it as a separate Aristotelian issue. This situation, with the quantity of the predicate mentioned by Hamilton, was also drawn by Venn diagrams (Venn I88ı: 6); 

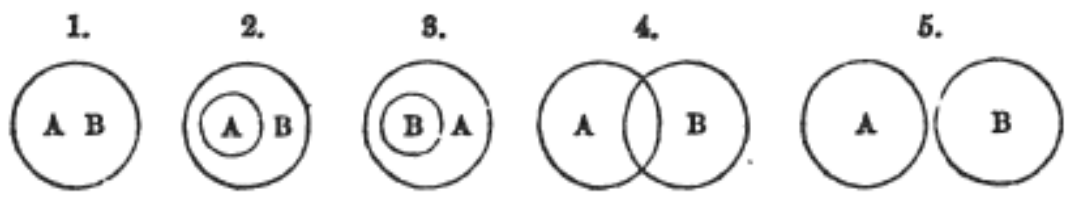

Here, for Aristotle, protasis holds in this manner:
A: I, 2
I: I, 2, 3, 4
E: 5
O: $3,4,5$

Aristotle's system contained all of them, so it is appropriate to be able to work on them. However, this has no independently place in Aristotle's system as it mentioned above.Finally, in Aristotelian logic, there are four more types of proposition used in syllogisms. These are different than the four kinds of proposition taken in classical logic, but in this case we can talk about Aristotle's logic having eight proposition and four protases. This eight propositions is examined in terms of the four protases:

\section{Propositions}

Universal affirmative

Universal negative

Particular affirmative

Particular negative

Singular affirmative

Singular negative

Indefinite affirmative

Indefinite negative

\section{Protasis}

A

E

I

$\mathrm{O}$

A

E

I

$\mathrm{O}$

And we see that, Aristotle asserts propositions in De Interpretaione and protases in Analytica Priora as follows: 


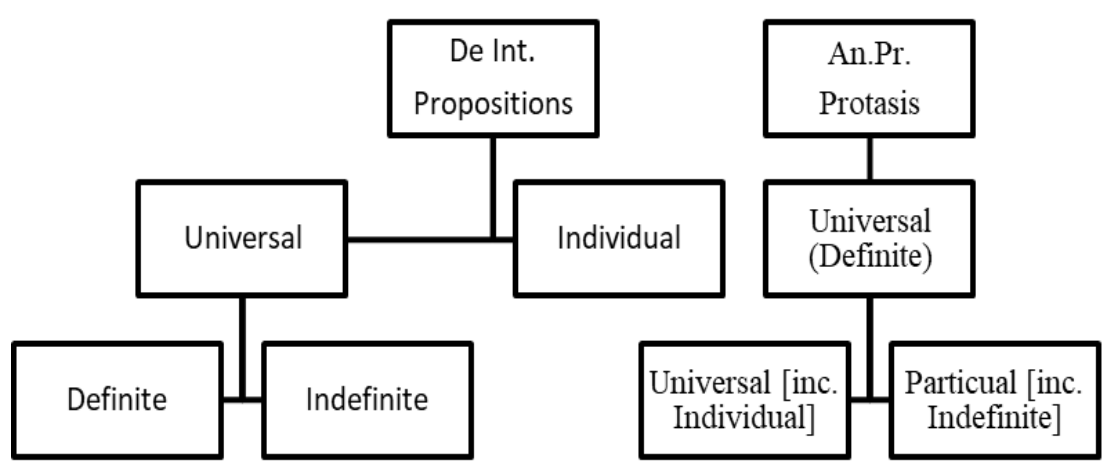

In De Interpretatione, Aristotle's inquiry is almost entirely taken up from a grammatical perspective. In Prior Analytics, on the other hand, his research has turned to the formal side. This is because, in part, that Aristotle has used different terms and classification in these works. Aristotle examines many features of propositions in De Interpretatione, such as how they are created, used, and classified in language. Formal use of these propositions leads to great confusions, ${ }^{28}$ however, so he reorganized the topic in Analytica Priora with an alternative concept, protasis. With this modification, syllogism theory operates more regularly and precisely. This transition is a significant change. From the view of formal language, we can say that Aristotle's deductive language generated 'simple propositions' by 'protasis'. This is given a way to show that Aristotle was in a position to grammatical in De Interpretatione and formal in Prior Analytics. Furthermore, Hamlyn (Hamlyn I96I: III) says that De Interpretatione is the most grammatical of Aristotle's consideration via predication. Herewith this event can be fixed via many ways.

\section{References}

Aristotle (2014). Complete Works of Aristotle, vol. I. (Ed. J. Barnes). New Jersey: Princeton University Press.

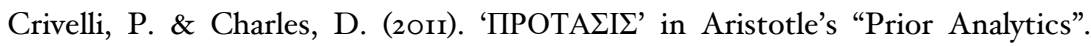
Phronesis, 56 (3), 193-203.

Corcoran, J. and Boger, G. (20II). Protasis in Prior Analytics: Proposition or

\footnotetext{
${ }^{28}$ For instance, the total number of possible syllogism by protasis is 192 , but by simple propositions is 1536 . For calculating method see: Williamson, C. (1988), 'How many syllogisms are there?', History and Philosophy of Logic, 9, p.79
} 
Premise? Bulletin of Symbolic Logic, 17, 15I-152.

Hamilton, W. (I860). Lectures on Metaphysics and Logic, vol. 2. London: Blackwood.

Hamlyn, D. W. (I96I). Aristotle on Predication. Phronesis, 6 (2): IIO-I26.

Ibn-Sīnā. (1984). Remarks and Admonitions: Part One: Logic. (Trans. S. C. Inati).

Toronto: Pointifical Institute of Mediaeval Studies.

Łukasiewicz, J. (1957). Aristotle's Syllogistic from the Standpoint of Modern Formal Logic. Oxford: Clarendon Press.

Minio-Paluello, L. (Ed.) (1949). Aristotelis Categoriae et Liber de Interpretatione. Oxford: Clarendon Press.

Ross, W. D. and Minio-Paluello, L. (Eds.) (1964). Aristotelis Analytica Priora Et Posteriora (Oxford Classical Texts). Clarendon Press.

Tredennick, H. \& Cooke, H. P. (1938). Aristotle: Categories. On Interpretation. Prior Analytics. Cambridge, Mass: Harvard University Press.

Venn, J. (I88I). Symbolic Logic. London: Macmillan \& Co.

Whitaker, C. W. A. (2002). Aristotle's De Interpretatione: Contradiction and Dialectic.

Oxford: Clarendon Press.

Williamson, C. (1988). How Many Syllogisms Are There? History and Philosophy of Logic, 9, 77-85.

Öz: Çalıșmamızda Aristoteles'in önermeleri nitelik ve nicelik bakımından nasıl oluşturduğu açıklanacak, bu önermelerin kıyasta öncüller olarak nasıl alındığı açılanacaktır. Aristoteles De Interpretatione'de 'apophansis' ve Analytica Prio$r a$ 'da 'protasis' kavramlarını incelemiştir. Bunları olumlu ve olumsuz olarak niteliklerine göre ayırmıs, bununla birlikte niceliklerine göre sınıflandırmalarında ise farklı bir bakıș açısı izlemiștir. Apophansislerin ayrımları terimlerin tekil ve tümel alınmıș olmasına göre değerlendirilmiș buna ilaveten yüklemlenmeleri de değerlendirmeye alınmıștır. Protasisleri incelerken önermelerin gruplandırmalarını yeniden düzenlemiş ve yüklenmelerinin özelliklerine göre yeniden gruplandırmıștır. De Interpretatione ve Analytica Priora arasındaki yapısal fark, Aristoteles'in bu iki kavramın kullanımını dikkatli bir șekilde inceleyerek ortaya çıkar.

Anahtar Kelimeler: Önerme, protasis, apophansis, tekil, tümel, Aristoteles mantığ1. 